Article

\title{
Polyphenol-Enriched Plum Extract Enhances Myotubule Formation and Anabolism while Attenuating Colon Cancer-induced Cellular Damage in C2C12 Cells
}

\author{
Faten A. Alsolmei ${ }^{1,2}{ }^{,}$Haiwen Li ${ }^{1}$, Suzette L. Pereira ${ }^{3}$, Padmavathy Krishnan ${ }^{4}$, Paul W. Johns ${ }^{3}$ \\ and Rafat A. Siddiqui ${ }^{1, *}$ \\ 1 Food Chemistry and Nutrition Science Research Laboratory, Agricultural Research Station, College of \\ Agriculture, Petersburg, VA 23806, USA; fatenalsolmei@gmail.com (F.A.A.); hali@vsu.edu (H.L.) \\ 2 Department of Biology, College of Natural and Health Sciences, Virginia State University, \\ Petersburg, VA 23806, USA \\ 3 Abbott-Nutrition Division, Research and Development, 3300 Stelzer Road, Columbus, OH 43219, USA; \\ suzette.pereira@abbott.com (S.L.P.); paul.johns@abbott.com (P.W.J.) \\ 4 Valley Children's Hospital, Madera, CA 93636, USA; padmakrishnan@hotmail.com \\ * Correspondence: rsiddiqui@vsu.edu; Tel.: +(804)-524-5957
}

Received: 5 April 2019; Accepted: 11 May 2019; Published: 15 May 2019

\begin{abstract}
Preventing muscle wasting in certain chronic diseases including cancer is an ongoing challenge. Studies have shown that polyphenols derived from fruits and vegetables shows promise in reducing muscle loss in cellular and animal models of muscle wasting. We hypothesized that polyphenols derived from plums (Prunus domestica) could have anabolic and anti-catabolic benefits on skeletal muscle. The effects of a polyphenol-enriched plum extract (PE60) were evaluated in vitro on C2C12 and Colon-26 cancer cells. Data were analyzed using a one-way ANOVA and we found that treatment of myocytes with plum extract increased the cell size by $\sim 3$-fold $(p<0.05)$ and stimulated myoblast differentiation by $\sim 2$-fold $(p<0.05)$. Plum extract induced total protein synthesis by $\sim 50 \%$ $(p<0.05)$, reduced serum deprivation-induced total protein degradation by $\sim 30 \%(p<0.05)$, and increased expression of Insulin-Like Growth Factor-1 (IGF-1) by $\sim 2$-fold ( $p<0.05$ ). Plum extract also reduced tumor necrosis factor $\alpha(\mathrm{TNF} \alpha)$-induced nuclear factor $\kappa \mathrm{B}(\mathrm{NF} \kappa \mathrm{B})$ activation by $80 \%(p<0.05)$ in A549/NF-kB-luc cells. In addition, plum extract inhibited the growth of Colon-26 cancer cells, and attenuated cytotoxicity in C2C12 myoblasts induced by soluble factors released from Colon-26 cells. In conclusion, our data suggests that plum extract may have pluripotent health benefits on muscle, due to its demonstrated ability to promote myogenesis, stimulate muscle protein synthesis, and inhibit protein degradation. It also appears to protect muscle cell from tumor-induced cytotoxicity.
\end{abstract}

Keywords: cachexia; plum; cancer; muscle wasting; myoblasts; protein synthesis

\section{Introduction}

Skeletal muscle weakness and wasting, which is also referred as cachexia, is a major clinical problem for advanced cancer patients [1]. In 1932, Warren described cachexia as the most common cause of death across a variety of cancers in a post mortem study of 500 patients [2]. The term "Cachexia" is derived from the Greek words "kakos" and "hexis," meaning "bad condition." It is a multi-organ syndrome associated with and characterized by at least $5 \%$ body weight loss due to muscle and adipose tissue wasting [3]. Cancer cachexia is a multifactorial syndrome that is common in advanced malignancy occurring in $80 \%$ of patients, which cannot be reversed by nutritional support and leads 
to significant function deficits [4], and which is responsible for an estimated $20 \%$ of cancer-related deaths [5].

Colorectal cancer (CRC) patients are often presented with cachexia syndrome, which is a major contributor to colorectal cancer-related morbidity and mortality [4-8]. About 35 to $60 \%$ of CRC patients show some degree of muscle wasting and $28 \%$ lose $>5 \%$ of their body weight in the six months preceding diagnosis [9]. Blocking muscle wasting can prolong life even in the absence of effects on tumor growth [10].

Oxidative stress through activating initial steps in protein degradation via the ubiquitin-proteasome pathway and the activation of caspases contributes to muscular atrophy [11-13]. In addition, inflammation also leads to muscle atrophy and this is mediated through cytokine (e.g., tumor necrosis factor $\alpha(\mathrm{TNF} \alpha)$, interleukin-6 (IL-6), and interferon $\gamma(\operatorname{IFN} \gamma)$ ) induced activation of the nuclear factor кB (NF-kB) pathway [14].

Recent studies have shown that polyphenol-rich plant extracts prevent oxidative stress, reduce inflammation, and help reduce muscle atrophy. We have previously shown that curcumin treatment attenuated muscle wasting in cancer cachectic mice [15]. Supplementation with red grape polyphenols mitigated muscular atrophy in transforming growth factor (TGF) mice, a model of chronic inflammation, by reducing mitochondrial oxidative stress and by inhibiting caspase activation [16]. Grape seed extract supplementation effectively prevented muscle wasting in IL10-knock out mice [17]. Green tea polyphenol, catechins, protected normal and dystrophic muscle cells from oxidative damage [18]. Epigallocatechin-3-gallate (EGCG) supplementation preserved muscle in sarcopenic rats [19] and attenuated skeletal muscle atrophy caused by experimentally induced cancer cachexia in in mice [20]. More recently, ursolic acid—a polyphenol present in apple peels, basil leaves, prunes, and cranberries [21] — has been shown to increase muscle mass in mice exhibiting fasting-induced muscle atrophy [22]; it has also increased muscle mass, fast and slow fiber size, grip strength, and exercise capacity in mice with diet-induced obesity [23]. These observations clearly suggest that intake of polyphenols can be beneficial in preserving muscle mass.

The common plum (Prunus domestica) is well known to be rich in polyphenols and contains unique phytonutrients called neochlorogenic and chlorogenic acid which have high antioxidant activities. Among functional foods, plums are also considered "super foods" since their consumption has been associated with the decrease in chronic degenerative diseases and circulatory and digestive issues [24]. Dried plums have been shown to reduce symptoms of arthritis in an inflammation model [25]. These effects are attributed to their high polyphenolic composition and related high antioxidant activity [26]. Plums have several health benefits and studies have found that plums also initiate anti-cancer mechanisms that may help prevent the growth of cancerous cells and tumors [27-29].

In addition, plums have been extensively studied for their effects on bone health [30,31]. Plums contain caffeic acid (the polyphenol component of neochlorogenic and chlorogenic acids) and rutin, which have been shown to inhibit the deterioration of bone tissues and prevent diseases such as osteoporosis in postmenopausal women [32]. Research has also shown that regular consumption of dried plums helps in the restoration of bone density lost to aging [33].

Formation of bone and much of the skeletal tissues is derived from the proliferation and differentiation of skeletal stem cells. As dried plum was found to be a potent regulator of bone health, it is possible that plum and its associated polyphenols may have benefits on other cells of musculoskeletal system. Thus, in the present study, we sought to investigate the effect of a polyphenol-enriched plum extract on muscle cell growth and differentiation, and on muscle protein synthesis and degradation in vitro. In addition, we explored the effect of plum extract on inflammation as well as studied its effect on colon cancer cells. 


\section{Materials and Methods}

\subsection{Materials}

Dulbecco's modified Eagle's medium (DMEM), fetal bovine serum (FBS), horse serum, and Penicillin-Streptomycin solution were purchased from Gibco-Thermo-Fisher Scientific (Grand Island, NY, USA). L-[2,3,4,5,6-3H] Phenylalanine and L-[Ring-3, 5-3H]-Tyrosine was purchased from Perkin-Elmer (Waltham, MA, USA), Prune extract-60\% enriched polyphenol extract (PE60) was purchased from PL Thomas (Morristown, NJ, USA). All other chemicals were of reagent grade, and were purchased from Sigma Chemical Co. (St. Louis, MO, USA).

\subsection{Composition of the PE60-Plum Extract}

Free gallic acid, 3-cholorogenic acid, rutin, free quercetin, and proanthocyanidins were determined with an Agilent Technologies (Wilmington, DE, USA) Model 1200 HPLC System equipped with a Model G1311A quaternary pump, Model G1322A vacuum degasser, Model G1329A autosampler, Model G1316A thermostatted column compartment, a Model G1315B diode array detector, and a Chem Station data processor. The separations were performed with a YMC-Pack ODS-AQ analytical column $(4.6 \times 250 \mathrm{~mm}, 5 \mu \mathrm{m}, \mathrm{P} / \mathrm{N}$ AQ12S05-2546WT, Waters Corporation, Milford, MA, USA), using mobile phase $\mathrm{A}=1000 / 100(v / v) 0.05 \mathrm{M} \mathrm{KH} 2 \mathrm{PO} 4$, pH 2.9/acetonitrile, and mobile phase $\mathrm{B}=200 / 800(v / v)$ Milli-Q Plus water/acetonitrile, a column temperature of $40{ }^{\circ} \mathrm{C}$, an injection volume of $5 \mu \mathrm{L}$, and the analytes were quantified at signals of $280 \mathrm{~nm} / 590 \mathrm{~nm}$ (for gallic acid and the proanthocyanidins), $330 \mathrm{~nm} / 590 \mathrm{~nm}$ (for 3-chlorogenic acid), and $375 \mathrm{~nm} / 590 \mathrm{~nm}$ (for rutin and quercetin). The elution program was $0 \%$ mobile phase B from 0 to $5 \mathrm{~min}, 0$ to $60 \%$ (linear gradient) mobile phase B from 5 to $35 \mathrm{~min}, 100 \%$ mobile phase B from 35 to $40 \mathrm{~min}$, and $0 \%$ mobile phase B from 40 to $55 \mathrm{~min}$ (end). The PE60 extract was prepared for analysis by stirring (at room temperature for $15 \mathrm{~min}$ ) $0.250 \mathrm{~g}$ in $100 \mathrm{~mL}$ of 50/50 (v/v) 0.05 M citric acid/methanol. The determinations were calibrated with standard solutions of gallic acid, 3-chlorogenic acid, rutin hydrate, and quercetin dihydrate (all obtained from Sigma-Aldrich, St. Louis, MO, USA), also prepared in the citric acid/methanol medium. The proanthocyanidin content was estimated by peak area proportionation vs. the corresponding peak areas (at $280 \mathrm{~nm} / 590 \mathrm{~nm}$ ) of grapeseed extracts (from Kikkoman, Polyphenolics, and Seppic) of known (i.e., label claim) proanthocyanidin content, included in the analysis. The anthocyanin concentration was estimated by a published colorimetric method [34]. During present investigation, minor isomers of chlorogenic acid (4-chlorogenic acid, 5-chlorogenic acid) were not determined.

\subsection{Characterization of Anti-Oxidation Capacity of the Plum Extract}

The PE60 (Lot PE6009-1601) extract was dissolved in water $(10 \mathrm{mg} / \mathrm{mL})$ and then centrifuged at $1500 \times g$ for $10 \mathrm{~min}$ to remove any insoluble material. The dissolved material was sterile filtered and the filtrate was assayed for total polyphenols by the Folin Ciocalteu method [35], for total flavonoids by the $\mathrm{AlCl} 3$ complexation method [36], for anti-oxidant activity by the DPPH assay [37], and for oxygen scavenging activity by the ABTS assay [38], as described.

\subsection{Cell Culture}

C2C12 cell line (mouse myoblasts) were obtained from American Type Culture Collection (Manassas, VA, USA). The undifferentiated cells were grown in complete media consisting of Dulbecco's modified Eagle's medium (DMEM, $4.5 \mathrm{mg} / \mathrm{mL}$ glucose) supplemented with heat-inactivated fetal calf serum $(10 \%)$, penicillin $(100$ units $/ \mathrm{mL})$, and streptomycin $(100 \mu \mathrm{g} / \mathrm{mL})$ at $37^{\circ} \mathrm{C}$ in the presence of $5 \% \mathrm{CO}_{2}$. The myoblasts were differentiated into myotubes by culturing them into differentiation medium, consisting of DMEM supplemented with heat-inactivated horse serum (5\%), penicillin (100 units/mL), and streptomycin $(100 \mu \mathrm{g} / \mathrm{mL})$ for five days. 


\subsection{Determination of C2C12 Myoblast Cell Size}

Muscles cells were grown in a 96-well plate for $24 \mathrm{~h}$ in $100 \mu \mathrm{L}$ complete media. Cells were then treated with $0,50,100,150$, and $200 \mu \mathrm{g} / \mathrm{mL}$ of extract for $48 \mathrm{~h}$ to evaluate a dose-response effect of plum extract. After incubations, the cells were observed under a microscope and pictures (100 $\times$ magnification) were taken using a Nikon microscope with calibrated objectives. The size of cells was determined using Element-BR software (Nikon Instruments Inc, Melville, NY, USA).

\subsection{Assaying C2C12 Myoblast Differentiation}

Muscle cells were initially cultured in a 96-well plate for $24 \mathrm{~h}$ in $100 \mu \mathrm{L}$ complete media. Cells were then incubated with $0,50,100$, and $200 \mu \mathrm{g} / \mathrm{mL}$ plum extract for five days and the medium containing corresponding concentration of plum extract was changed every $24 \mathrm{~h}$. After treatment, the cells were washed once with PBS, and then fixed with cold $4 \%$ paraformaldehyde for $10 \mathrm{~min}$ on ice. The cells were washed three times with PBS and the monolayer was treated with blocking solution containing $2 \%$ albumin. The cells were then incubated with anti-myosin antibody at room temperature for $2 \mathrm{~h}$. Cell were washed again and then incubated with anti-mouse Alexa-488 antibody (Abcam, Cambridge, MA) for two hours. Cells were washed again three times with PBS and the nuclei were stained briefly with Hoechst 33342 dye (1:2000 dilution). Pictures were taken at $200 \times$ magnification using a Nikon Fluorescent Microscope (Nikon Instruments Inc, Melville, NY 11747, USA). Myotubes were defined as myosin positive cells with 2 or more fused nuclei.

\subsection{Protein Synthesis in Cultured C2C12 Myotubules}

C2C12 cells $(375,000)$ were initially plated on a 12-well tissue culture plate that was initially coated with $2 \%$ gelatin. Cells were differentiated for five days in $5 \%$ horse serum (media was changed every two days) and then starved for $30 \mathrm{~min}$ by replacing the media with $1 \mathrm{ml}$ PBS. The cells were then treated with $0,50,100$, and $200 \mu \mathrm{g} / \mathrm{mL}$ of plum extract in PBS, spiked with $\left[{ }^{3} \mathrm{H}\right]$ phenylalanine $(1 \mu \mathrm{Ci} /$ well), and incubated for $2 \mathrm{~h}$ at $37^{\circ} \mathrm{C}$. The reaction was stopped by placing the plates on ice. Wells were washed two times with DPBS-media containing $2 \mathrm{mM}$ cold phenylalanine. Further, $1 \mathrm{~mL}$ of $20 \%$ cold trichloroacetic acid (TCA) solution was added to each well and plates were incubated on ice for $1 \mathrm{~h}$ for protein precipitation. Wells were washed two times with cold TCA and then the precipitated proteins were dissolved in $0.5 \mathrm{~mL}$ of $0.5 \mathrm{~N} \mathrm{NaOH}$ containing $0.2 \%$ Triton $\mathrm{X}-100$ overnight in a refrigerator. An aliquot $(5 \mu \mathrm{L})$ of the $\mathrm{NaOH}$ solubilized material was used for protein determination and the rest of the dissolved proteins were mixed with scintillation fluid and counted. Data is computed as $\mathrm{cpm} / \mathrm{mg}$ of proteins and then $\%$ change over control is calculated.

\subsection{Protein Degradation in C1C12 Myotubules}

C2C12 myoblasts were cultured and differentiated as described above. Cells were then labelled with $\left[{ }^{3} \mathrm{H}\right]$ Tyrosine $1 \mu \mathrm{Ci} / 1 \mathrm{~mL}$ in serum free-DMEM (SF-DMEM) for $24 \mathrm{~h}$. The unincorporated $\left[{ }^{3} \mathrm{H}\right]$ Tyrosine was removed by washing the cell monolayer three times with SF-DMEM containing $50 \mu \mathrm{M}$ cycloheximide (protein synthesis inhibitor) and $2 \mathrm{mM}$ non-labelled Tyrosine. Proteolysis was induced by serum deprivation for $48 \mathrm{~h}$ in the presence or absence of $50,100,200 \mu \mathrm{g} / \mathrm{mL}$ of plum extract in serum-free DMEM containing $50 \mu \mathrm{M}$ cycloheximide. The extent of protein degradation was assayed by monitoring release of radioactive tyrosine in the media after $48 \mathrm{~h}$ of incubation and was expressed as protein degradation in comparison to control (normalized to $100 \%$ ).

\subsection{Determination of Insulin-Like Growth Factor-1 (IGF-1) Expression}

Total RNA was extracted from C2C12 myotubules with RNeasy Plus Universal Mini Kit (Qiagen, Hilden, Germany), according to the manufacturer's instructions. The concentration and purity of RNA was determined by measuring the absorbance in a Nano drop spectrophotometer. RT2 First Strand Kit from Qiagen (Qiagen, Hilden, Germany) was used to synthesize first strand complementary DNA 
(cDNA). The gene expression levels were analyzed by Quantitative real-time RT-PCR conducted on the Bio-Rad CFX-96 Real-Time PCR System using RT2 SYBR Green Master mix (Bio-Rad Laboratories, Hercules, CA). The primers (IGF: forward primer GGACCAGAGACCCTTTGCGGGG and reverse primer, AGCTCAGTAACAGTCCGCCTAGA; GAPDH: forward primer ATCCCATCACCATCTTCCAG and reverse primer CCATCACGCCACAGTTTCC) were designed. Hot-Start DNA Taq Polymerase was activated by heating at $95{ }^{\circ} \mathrm{C}$ for $10 \mathrm{~min}$ and real time PCR was conducted for 40 cycles $(15 \mathrm{~s}$ for $95^{\circ} \mathrm{C}, 1 \mathrm{~min}$ for $60^{\circ} \mathrm{C}$ ). All results were obtained from at least three independent biological repeats. Data were analyzed using the $\triangle \triangle \mathrm{CT}$ method. Glyceraldehyde-3-phosphate dehydrogenase (GAPDH) genes were used as house-keeping genes for expression calculation.

\subsection{Determination of NFkB Activation}

A549/NFkB-luc cells (Panomics Catalog No. RC0002) at $3 \times 10^{5} /$ well were seeded in $1 \mathrm{~mL}$ of Initial Growth Media (Dulbecco's Modified Eagle's medium containing 10\% FBS and 1\% Pen-Strep) in a 12-well plate. The cells were incubated in a humidified incubator at $37^{\circ} \mathrm{C}$ and $5 \% \mathrm{CO}_{2}$ for $24 \mathrm{~h}$ to allow cells to recover and attach. After washing the cells once with serum-free media containing penicillin (100 units/mL), and streptomycin $(100 \mathrm{mg} / \mathrm{mL}), 1 \mathrm{~mL}$ of this media was added to each well. Cells were pretreated with varying concentrations of plum extracts for $1 \mathrm{~h}$ at $37^{\circ} \mathrm{C}$ and $5 \% \mathrm{CO}_{2}$, and then $\mathrm{TNF} \alpha$ was added to achieve a final concentration of $2 \mathrm{ng} / \mathrm{mL}$ to all wells except control untreated cells. The cells were incubated in a humidified incubator at $37^{\circ} \mathrm{C}$ and $5 \% \mathrm{CO}_{2}$ for $6 \mathrm{~h}$. After treatment, the media was carefully removed. Cells were washed with PBS once and then lysed by $100 \mu \mathrm{L}$ of $1 \times$ lysis buffer. Assay for luciferase activity was performed according to assay manufacturer's (Promega P/N E1500) recommendations. The average relative luminescence units (RLU) were calculated and corrected for baseline quenching for each set of triplicate wells, using WinGlow software (PerkinElmer, Waltham, MA 02451, USA and Microsoft Excel (Microsoft Corporation, Redmond, WA 98073, USA). The data is reported as the relative percent inhibition of TNF $\alpha$ mediated NFKB activation on A549 cells.

\subsection{Effect of Plum Extract on Colon-26 Proliferation and its' Soluble Factor Induced Cytotoxicity on C2C12 Myotubules}

Colon 26 cells, a mouse colon carcinoma cell line, was obtained from American Type Culture Collection (Manassas, VA, USA). Effect of plum extract on Colon-26 cell proliferation was assayed using a Water-Soluble Tetrazolium-1 (WST-1) (Talkara, Shiga, Japan) assay as described previously [39]. To determine the effects of soluble factors released from Colon-26 on $\mathrm{C} 2 \mathrm{C} 12$ myotubules, conditioned media from Colon-26 culture was collected after $24 \mathrm{~h}$. of cultivation. The media was centrifuged at $2500 \times g$ for $20 \mathrm{~min}$ to remove cellular material. The clear supernatant (conditioned media) was diluted 1:10 with normal complete media. The $\mathrm{C} 2 \mathrm{C} 12$ differentiated myoblasts were then treated with normal complete medium or with Colon-26 conditioned medium with or without $50 \mu \mathrm{g} / \mathrm{mL}$ plum extract. A lower dose of plum extract $(50 \mu \mathrm{g} / \mathrm{mL})$ was used to avoid a direct effect of higher dose of plum extract $(100 \mu \mathrm{g} / \mathrm{mL}$ or $200 \mu \mathrm{g} / \mathrm{mL})$ on protein synthesis and degradation. The cell viability was assayed using a WST-1 assay. Control cells were subjected to equal amounts of non-conditioned media.

\subsection{Data Analysis}

The data is expressed as mean \pm SD for at least three replicates. All comparisons were made by one-way ANOVA with Tukey's -HSD-post-hoc test using SPSS Statistics 20 software. All significant differences are reported at $p<0.05$ and indicated by "**". 


\section{Results}

\subsection{Characterization of PE60 Plum Extract Composition and Anti-Oxidation Properties}

As shown in Table 1, the major components identified in the polyphenol-enriched PE60 plum extract are proanthocyanidins, along with minor components such as anthocyanidins, 3-chlorogenic acid, rutin, quercetin (free), and gallic acid (free).

The PE60 was also characterized by determining total phenolic content (TPC), total flavonoid content (TFC), anti-oxidant activity (DPPH assay), and oxygen scavenging activity (ABTS). The data in Table 2 shows that the content of TPC was in the same range as reported by the commercial vendor $(60 \%)$. The data indicate that the PE60 contained TPC in range 525-575 mg/g of dry extract. The TFC was in 480-560 mg/g dry weight range. The anti-oxidation effects as determined by inhibition of DPPH oxidation and ABTS assay ranged from 3280-3460 and 4000-4500 $\mu \mathrm{M}$ Trolox equivalents/g, respectively.

Table 1. Characterization of composition of polyphenol-enriched plum extract (PE60).

\begin{tabular}{|c|c|c|c|}
\hline Component & $\begin{array}{c}\text { Concentration } \\
(\mathrm{g} \text { per } 100 \mathrm{~g}) n=3\end{array}$ & Flavonoid Type (USDA) & Analytical Method \\
\hline Anthocyanins & $\begin{array}{c}0.391 \pm 0.020 \\
(\mathrm{rsd}=5.1 \%)\end{array}$ & Anthocyanidin & Colorimetric \\
\hline 3-chlorogenic acid & $\begin{array}{c}1.76 \pm 0.01 \\
(\mathrm{rsd}=0.6 \%)\end{array}$ & Hydroxycinnamic acid & $\mathrm{LC} / \mathrm{UV}^{*}$ \\
\hline Rutin & $\begin{array}{c}1.12 \pm 0.01 \\
(\mathrm{rsd}=0.6 \%)\end{array}$ & Flavanol & $\mathrm{LC} / \mathrm{UV}$ * \\
\hline Quercetin (free) & $\begin{array}{c}0.718 \pm 0.005 \\
(\mathrm{rsd}=0.7 \%)\end{array}$ & Flavanol & $\mathrm{LC} / \mathrm{UV}^{*}$ \\
\hline Gallic acid (free) & $\begin{array}{c}0.381 \pm 0.004 \\
(\mathrm{rsd}=1.1 \%)\end{array}$ & Hydroxybenzoic & LC/UV* \\
\hline Proanthocyanidins & $\begin{array}{c}60 \pm 10 \\
(\mathrm{rsd}<2 \%)\end{array}$ & Flavan-3-ol & $\mathrm{LC} / \mathrm{UV}^{*}$ \\
\hline
\end{tabular}

Contents in PE60 plum extract were determined either using an Agilent Technologies Model 1200 HPLC System (Wilmington, DE, USA) or a colorimetric method as described in Section 2.2 in the text. Values are mean \pm SD of three experiments. * LC/UV = liquid chromatography/ultraviolet light detection

Table 2. Characterization of anti-oxidation properties of PE60.

\begin{tabular}{ccc}
\hline Assays & Units & Mean \pm SD \\
\hline Total Phenolic Content (TPC) & $\mathrm{mg} / \mathrm{g}$ & $542.44 \pm 24.75$ \\
Total Flavonoid Content (TFC) & $\mathrm{mg} / \mathrm{g}$ & $520.00 \pm 40.10$ \\
Anti-oxidant activity (DPPH) & $\mu \mathrm{M}$ Trolox Equivalent/g & $3375 \pm 90$ \\
Oxygen Scavenging Activity (ABTS) & $\mu \mathrm{M}$ Trolox Equivalent/g & $4250 \pm 250$ \\
\hline
\end{tabular}

The anti-oxidation properties of PE60 plum extract were determined using specific assays (TPC: total phenolic content, TFC: total flavonoid content, DPPH: 2,2-diphenyl-1-picrylhydrazyl, ABTS: 2,2'-azino-bis\{3-ethylbenzothiazoline6 -sulfonic acid\}) as described in Section 2.3 in the text. Values are mean \pm SD of three experiments.

\subsection{Effect of PE60 Plum Extract on C2C12 Myoblast Size and Differentiation}

Plum extract had no cytotoxic effect on myoblast when used even at a high dose of $250 \mu \mathrm{g} / \mathrm{mL}$ (data not shown). It is evident from images that plum extract has some effect on cell proliferation; however, it was interesting to note that the plum extract increased the size of undifferentiated myoblasts cells in a dose-dependent manner (Figure 1a). The size of myoblast increased $\sim$ two-fold $(p<0.05)$ after treating cells with $50 \mu \mathrm{g} / \mathrm{mL}$ of plum extract when compared to that of untreated-control cells. Increase in myoblast size plateaued to a maximum increase of three-fold at $200 \mu \mathrm{g} / \mathrm{mL}$ concentration (Figure 1b). The effect of plum extract was also assessed on myoblast differentiation. Figure 2a indicates that the plum extract stimulated differentiation of myoblast in a dose-dependent manner using expression of myosin heavy chain as a marker for differentiation. The number of myotubes formed resulting from fusion of differentiated cells was increased by two-fold in cells treated with 
$100 \mu \mathrm{g} / \mathrm{mL}$ plum extract $(p<0.05)$ and by three-fold at $200 \mu \mathrm{g} / \mathrm{mL}(p<0.05)$ compared to that of control cells (Figure $2 b$ ).

a

$0 \mu \mathrm{g} / \mathrm{mL}$

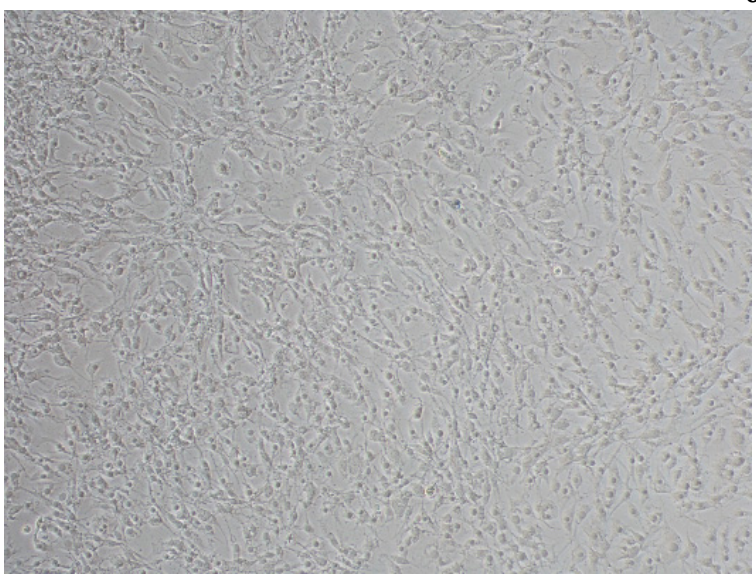

$50 \mu \mathrm{g} / \mathrm{mL}$

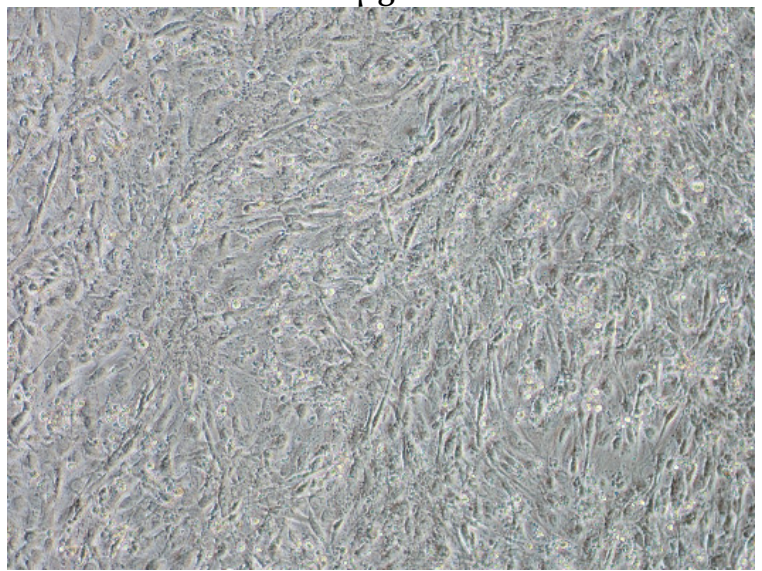

$150 \mu \mathrm{g} / \mathrm{mL}$

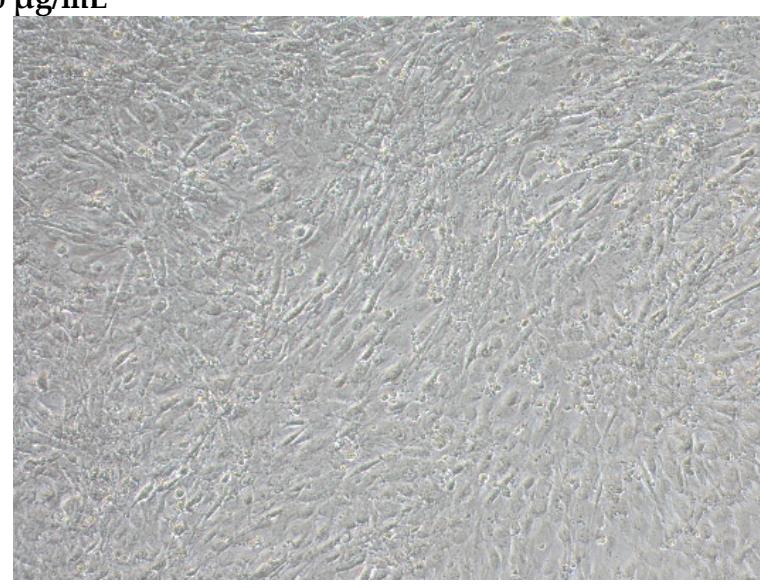

$100 \mu \mathrm{g} / \mathrm{mL}$

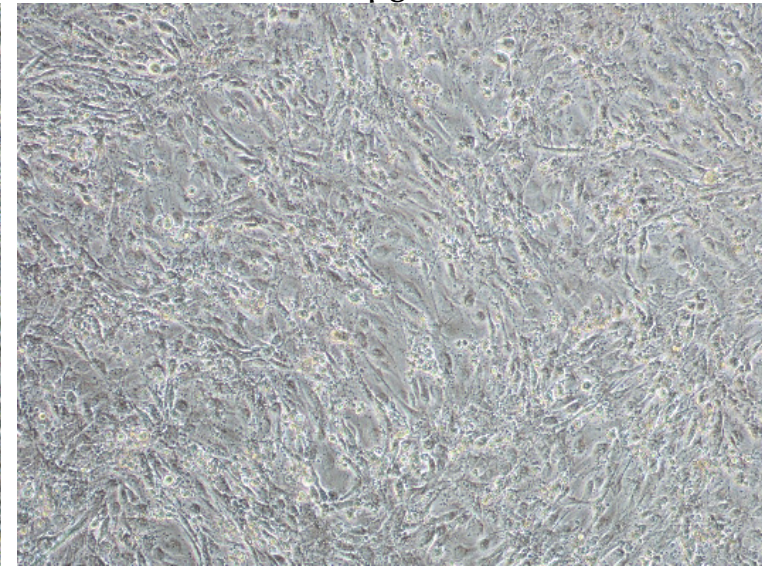

$200 \mu \mathrm{g} / \mathrm{mL}$

Plum Extract

Figure 1. Cont. 
b

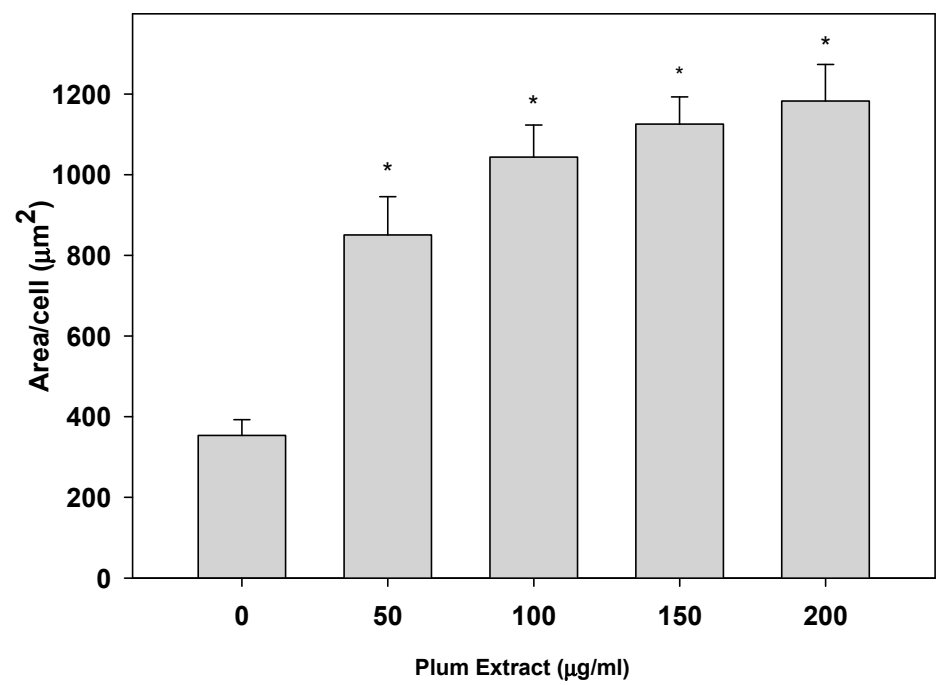

Figure 1. The effect of plum extract on $\mathrm{C} 2 \mathrm{C} 12$ myoblast cell size. (a) The representative pictures of myoblast after treatment with varying concentration of plum extract $(100 \times$ magnified images) taken by a Nikon Microscope. The bar represents a length of $500 \mu \mathrm{m}$. (b) The size of myoblast was determined using Element-BR software as described in "Materials and Methods". The data are expressed as mean \pm SD for at least three experiments. All comparisons were made to control (untreated cells) using one-way ANOVA; significant differences are reported at ${ }^{*} p<0.05$.

(a)

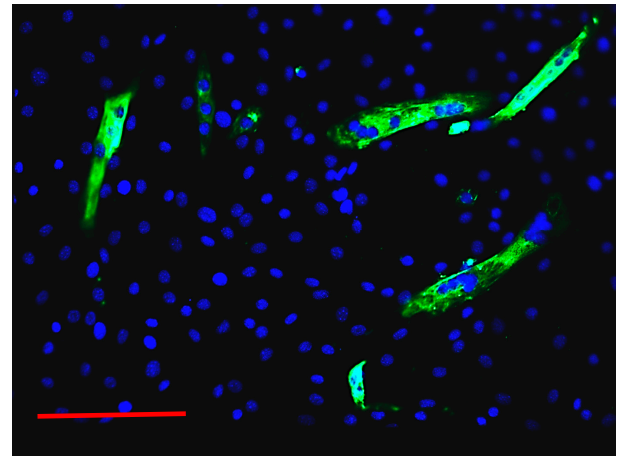

$0 \mu \mathrm{g} / \mathrm{mL}$

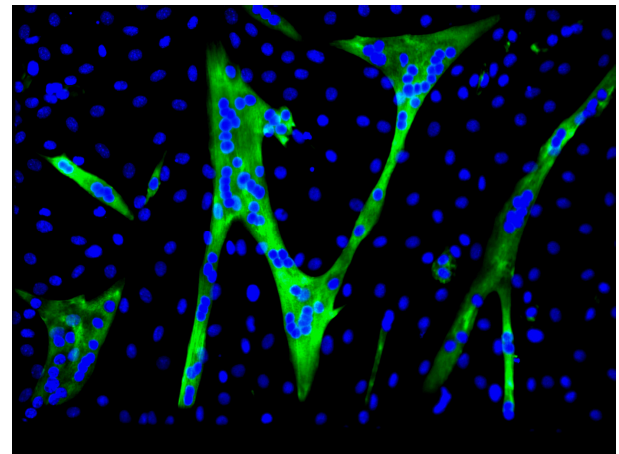

$100 \mu \mathrm{g} / \mathrm{mL}$

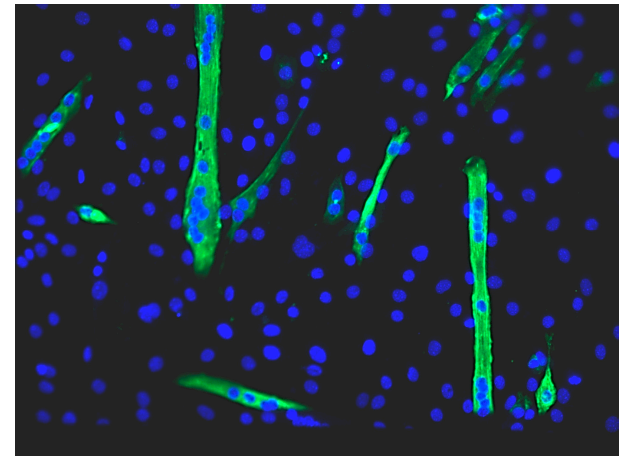

$50 \mu \mathrm{g} / \mathrm{mL}$

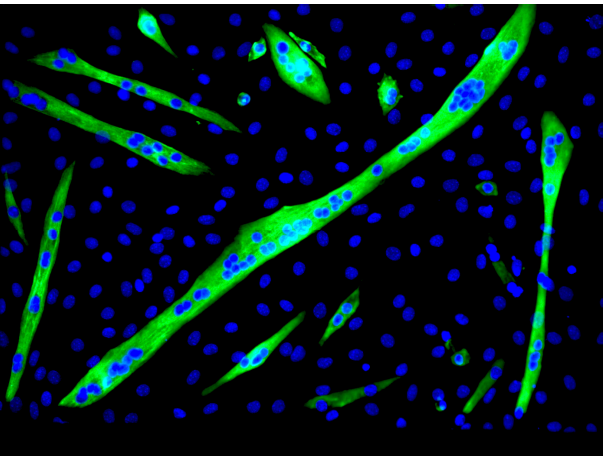

$200 \mu \mathrm{g} / \mathrm{mL}$

Plum Extract

Figure 2. Cont. 
(b)

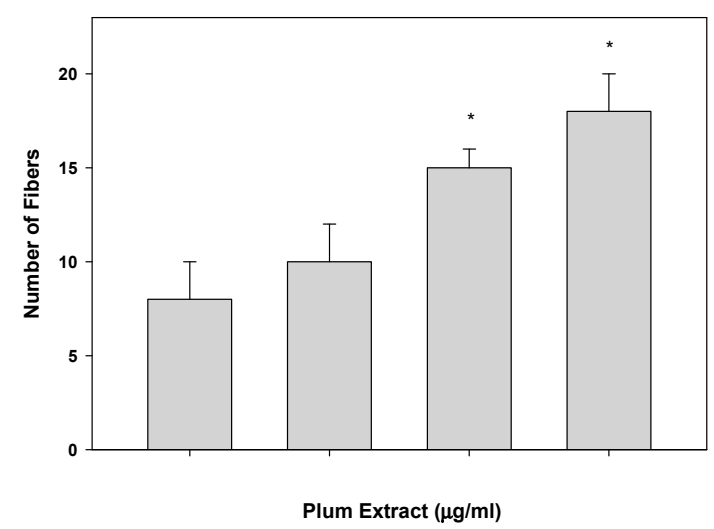

Figure 2. The effect of plum extract on $\mathrm{C} 2 \mathrm{C} 12$ myoblast differentiation. (a) Images of differentiated cells after treatment with varying concentration of plum extract showing nuclei stained in blue (Hoechst 33342) and myofibers stained in green (Alexa 488). Pictures were taken at 200× magnification using a Nikon Fluorescent Microscope. The bar represents a length of $300 \mu \mathrm{m}$. (b) Fused cells from five random fields were counted manually under 200× as described in "Materials and Methods". The data are expressed as mean $\pm \mathrm{SD}$ for at least three experiments. All comparisons were made to control (untreated cells) using one-way ANOVA; significant differences are reported at ${ }^{*} p<0.05$.

\subsection{Effect of PE60 Plum Extract on Myotubule Protein Synthesis}

Plum extract showed almost a linear increase in $\left[{ }^{3} \mathrm{H}\right]$ phenylalanine incorporation into proteins in a dose dependent manner in C2C12 myotubules (Figure 3). Doses of $100 \mu \mathrm{g} / \mathrm{mL}$ and $200 \mu \mathrm{g} / \mathrm{mL}$ of plum extract caused a significant increase in protein synthesis by $30 \%$ and $50 \%$, respectively $(p<0.05)$.

\subsection{Effect of PE60 Plum Extract on Myotubules Protein Degradation}

We also examined if plum extract could reduce myotubule protein degradation induced by serum starvation. Figure 4 revealed that plum extract did inhibit protein degradation in a dose-dependent manner. Doses of $100 \mu \mathrm{g} / \mathrm{mL}$ and $200 \mu \mathrm{g} / \mathrm{mL}$ significantly inhibited protein degradation by $20 \%$ and $30 \%$, respectively $(p<0.05)$.

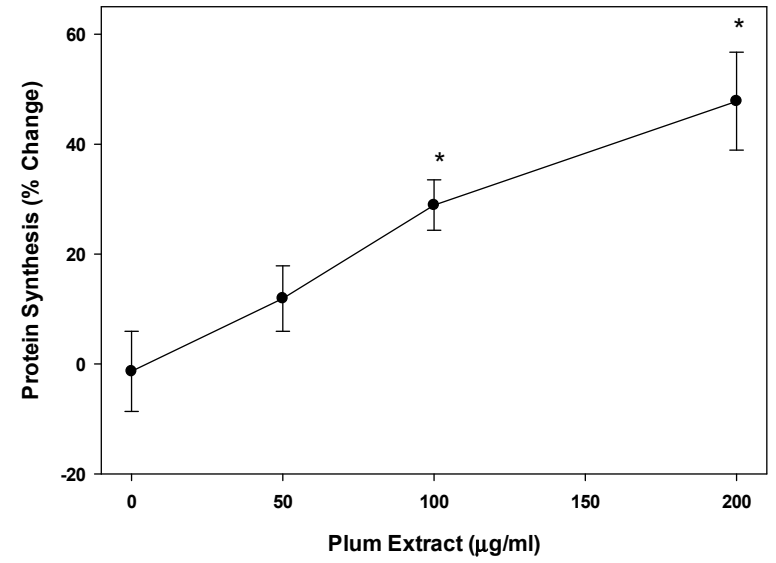

Figure 3. The effect of plum extract on myotubule protein synthesis. Protein synthesis was measure by the incorporation of labeled phenylalanine into total myotubule proteins in response to various levels of plum extract. Data were computed as $\mathrm{cpm} / \mathrm{mg}$ of proteins followed by calculation of $\%$ change over control. The data were expressed as mean \pm SD for at least three experiments. All comparisons were made to control (untreated cells) using one-way ANOVA; significant differences are reported at * $p<0.05$. 


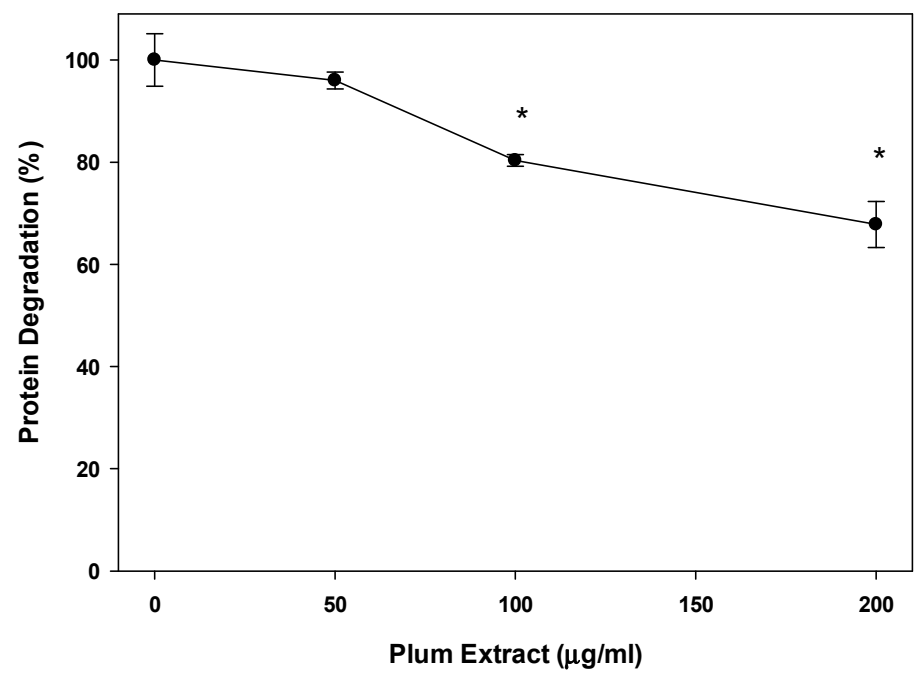

Figure 4. The effect of plum extract on myotubule protein degradation. Proteolysis was induced by $48 \mathrm{~h}$-serum starvation in the presence or absence of plum extract, and monitored by release of radioactive tyrosine from pre-labelled cells. Data were computed as $\mathrm{cpm} / \mathrm{mg}$ of proteins and then $\%$ change over control was calculated. The data were expressed as mean \pm SD for at least three experiments. All comparisons were made to control (untreated cells) using one-way ANOVA; significant differences are reported at $*<0.05$.

\subsection{Effect of PE60 Plum Extract on IGF-1 Expression in Myotubules}

Expression of IGF-1 mRNA in C2C12 myotubules upon treatment with plum extract is shown in Figure 5. Compared to that of untreated cells, low concentration of plum extract $(50 \mu \mathrm{g} / \mathrm{mL})$ has no significant effect on IGF-1 mRNA expression; however, it significantly stimulated IGF-1 expression when cells were treated at a higher dose $(100$ or $200 \mu \mathrm{g} / \mathrm{mL})$ plum extract.

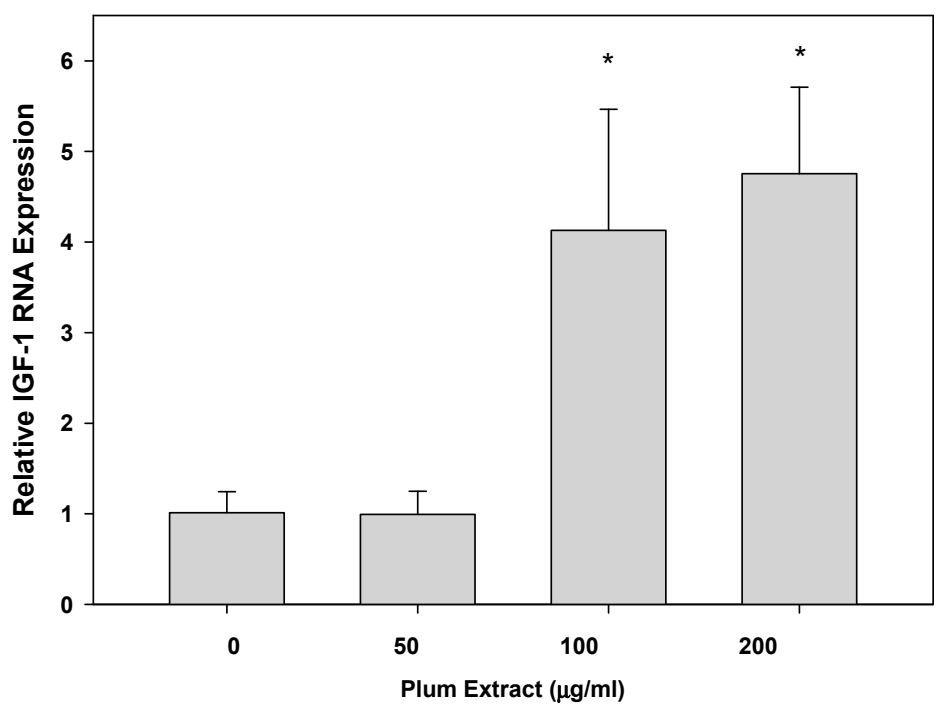

Figure 5. The effect of plum extract of IGF-1 gene expression. Total RNA was extracted from C2C12 myotubules treated with various concentrations of plum extract and compared to untreated control. All results were obtained from at least three independent biological repeats. Data were analyzed using the $\triangle \triangle C T$ method. Glyceraldehyde-3-phosphate dehydrogenase (GAPDH) genes were used as house-keeping genes for expression calculation. All comparisons were made to control (untreated cells) using one-way ANOVA; significant differences are reported at ${ }^{*} p<0.05$. 


\subsection{Anti-Inflammatory Effect of PE60 plum Extract in Vitro}

We evaluated the anti-inflammatory activity of plum extract by assessing its effect on TNF- $\alpha$-induced NFkB activation where the activity was measured in terms of luciferase activity of NFkB reporter system assay. Plum extract inhibited NFkB activation in a dose dependent manner (Figure 6). A dose response assay indicated that $\sim 40 \%$ inhibition $(p<0.05)$ of TNF- $\alpha$-mediated NFkB activation was achieved at $25 \mu \mathrm{g} / \mathrm{mL}$ plum extract, and $>80 \%$ inhibition $(p<0.05)$ of TNF- $\alpha$-mediated $\mathrm{NFkB}$ activation was achieved at $50 \mu \mathrm{g} / \mathrm{mL}$ plum extract.

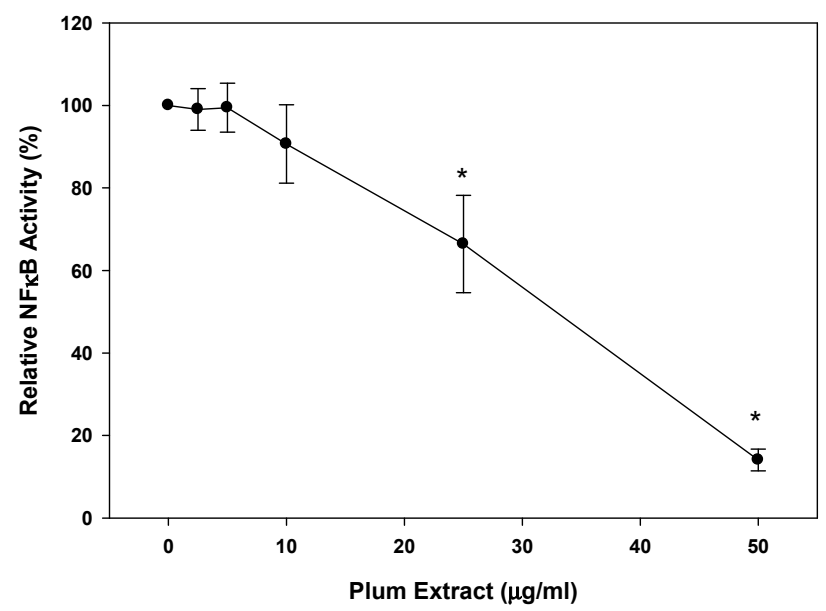

Figure 6. Effects of plum extract on NFkB activation. The effect of plum extract on TNF $\alpha$-mediated NFkB activation was measured in the A549/NFkB-luc reporter stable cell line. Activity was measured in terms of luciferase activity. The data are reported as the relative percent inhibition of TNF $\alpha$-mediated NFkB activation. The data are expressed as mean \pm SD for at least three experiments. All comparisons were made to control (untreated cells) using one-way ANOVA; significant differences are reported at $* p<0.05$.

\subsection{Effect of PE60 Plum Extract on Colon-26 Mouse Adenocarcinoma Cell Line}

When Colon-26 cells were treated with plum extract, the cells viability was reduced in a dose-dependent manner reaching $\sim 80 \%$ reduction $(p<0.05)$ at $150 \mu \mathrm{g} / \mathrm{mL}$. Upon further increasing the concentration of plum extract, the cell viability was further reduced $90 \%(p<0.05)$ at $200 \mu \mathrm{g} / \mathrm{mL}$ (Figure 7).

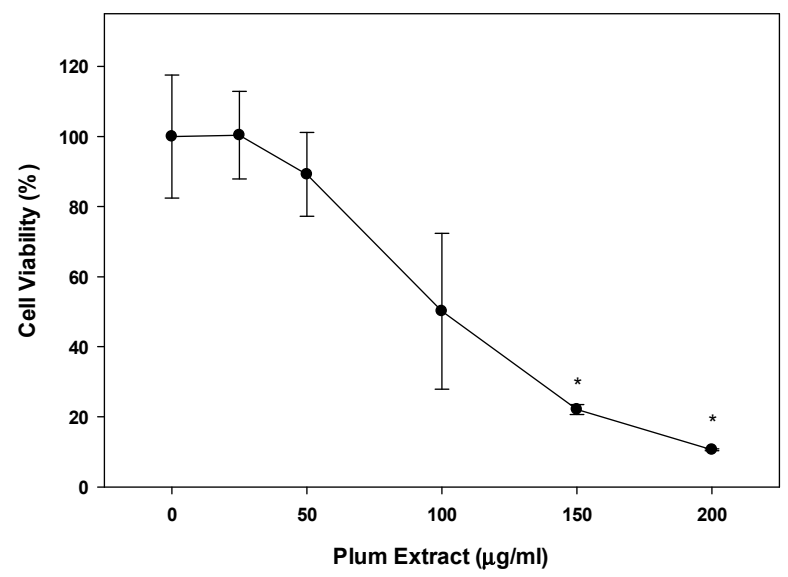

Figure 7. Effect of plum extract on Colon-26 adenocarcinoma cells. Data were calculated as \% inhibition of cell growth in response to various concentrations of plum extract. The data are expressed as mean \pm SD for at least three replicates. All comparisons were made to control (untreated cells) using one-way ANOVA; the significant differences are reported at ${ }^{*} p<0.05$. 


\subsection{Effect of PE60 Plum Extract on C2C12 Cell Viability in Response to Colon-26 Cells Cytotoxicity-Inducing Factors}

Mouse derived Colon-26 adenomacarcinoma cells are known to induce muscle wasting in rodents [40]. The effect of these circulating soluble factors released by Colon- 26 was examined on growth of $\mathrm{C} 2 \mathrm{C} 12$ myotubules in vitro in presence or absence of plum extract. Figure $8 \mathrm{a}, \mathrm{b}$ shows that in the absence of plum extract, soluble factors released in media derived from Colon- 26 cells caused a significant reduction of $\mathrm{C} 2 \mathrm{C} 12$ cell viability by $\sim 25 \%(p<0.05)$. However, in the presence of plum extract, the negative effects of Colon-26-derived media on $\mathrm{C} 2 \mathrm{C} 12$ viability was prevented and the cell viability was maintained to a similar level that was seen in the untreated cells.

a

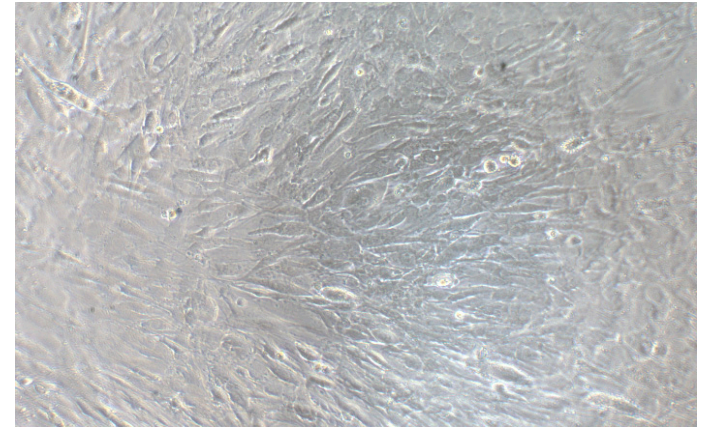

(i) Normal Medium

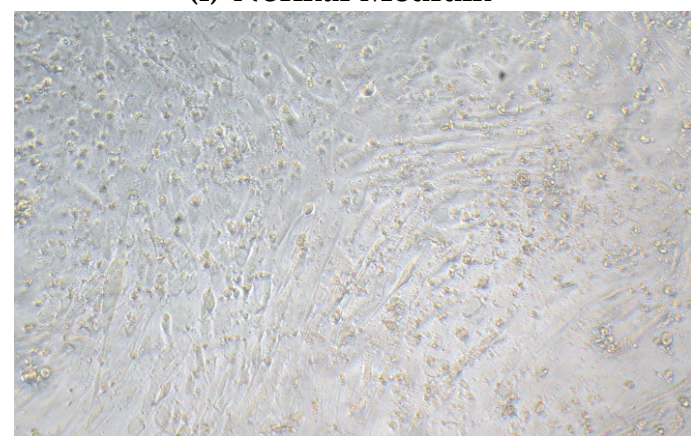

(iii) Colon-26 Conditioned medium

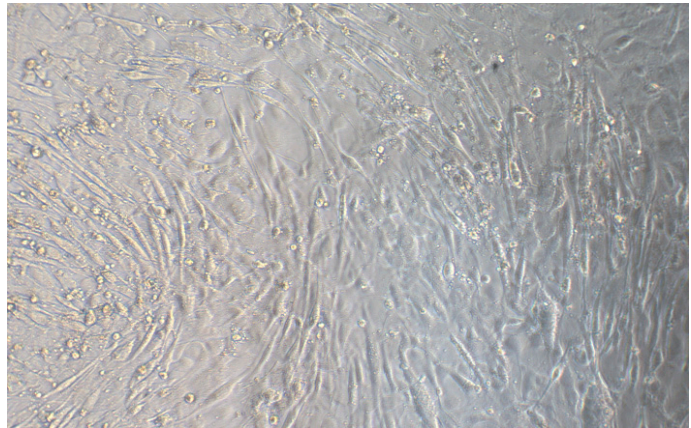

(ii) Normal Medium + Plum Extract

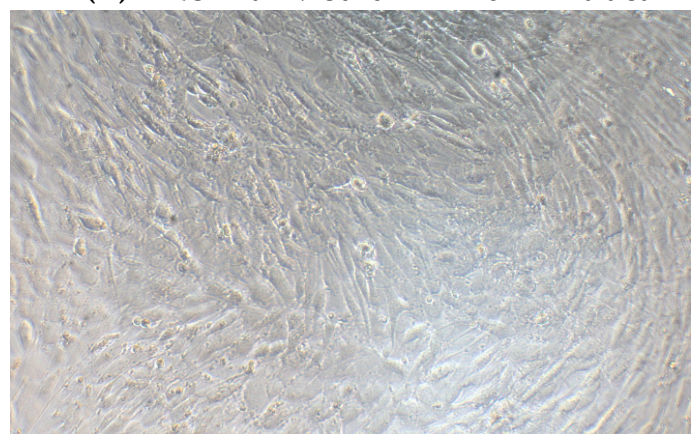

(iv) Colon-26 Conditioned medium + Plum Extract

b

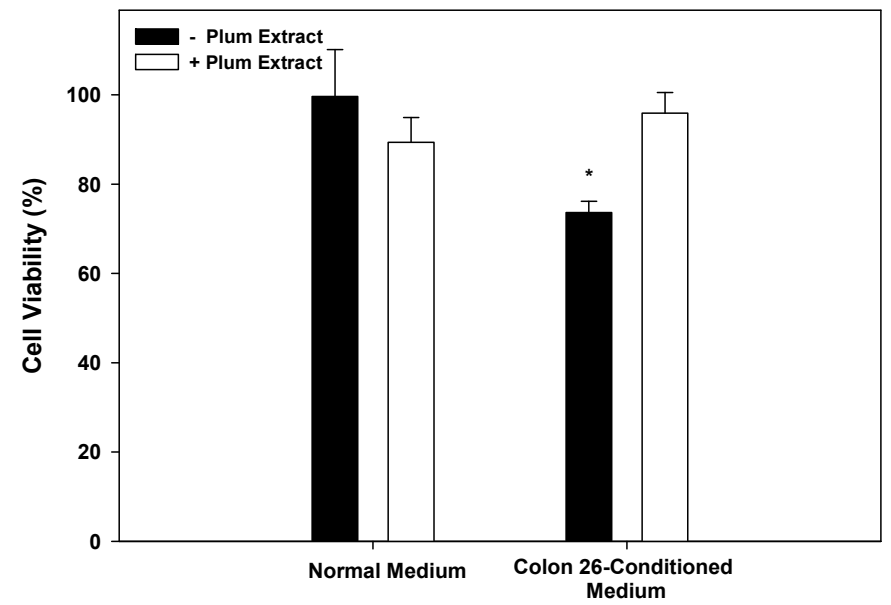

Figure 8. The effect of plum extract on $\mathrm{C} 2 \mathrm{C} 12$ viability in response to Colon-26-induced cytotoxicity. (a) Differentiated C2C12 myotubes were treated with normal medium (i \& ii) or Colon-26-conditioned medium (iii \& iv) in the absence (i \& iii) or presence (ii \& iv) of plum extract (50 $\mu \mathrm{g} / \mathrm{mL}$ ). (b) The viability of $\mathrm{C} 2 \mathrm{C} 12$ myotubules were determined using WST-1 assay. The data is expressed as mean \pm SD for at least three experiments. All comparisons were made to control (untreated cells) using one-way ANOVA; significant differences are reported at $* p<0.05$. 


\section{Discussion}

In our study, we sought to investigate if plums had benefits on skeletal muscle. Specifically, we selected to use a plum extract that was enriched in polyphenols ( $60 \%$ polyphenols) because the health benefits of plum have been partly attributed to its high polyphenol content [41-43]. Our data indicates that about $95 \%$ of total phenolic content in the plum extract used was present in the form of flavonoids. This data is not surprising as fruits are often reported to have phenolic compounds which are high in flavonoids with a range of $90-100 \%$ [44]. The anti-oxidant activity in the plum extract was found to be in range of 3-4 mM of Trolox equivalent $/ \mathrm{g}$, which is higher than that of turmeric $(0.27-0.35$ $\mathrm{mM}$ Trolox eq/g) and mulberry (1-2 mM Tolox eq/g), but lower than green tea (13-17 mM Trolox eq/g) and pomegranate (20-25 $\mathrm{mM}$ Trolox eq/g) [45-49].

Dried plum has previously been reported to have health benefits on bone. In rat models of osteoporosis, dried plum intake resulted in prevention and reversal of bone loss [50,51]. A three-month clinical intervention study showed that dried plum intake improved biomarkers of bone formation in postmenopausal women, whereas longer-term intake of dried plum resulted in mitigating loss of bone mineral density [31]. The present study was designed to analyze the effects of plum extract on muscle metabolism in $\mathrm{C} 2 \mathrm{C} 12$ myotubules. In our initial experiments, the effect of plum extract was tested on myoblast viability. The data show that this plum extract has no toxicity on the muscle cells, even at very high doses. These results are consistent with prior literature on plum effects on non-diseased cells [52]. The maintenance of muscle mass is dependent on synthesis of new proteins and breakdown of old or damaged proteins. If these processes are balanced, the muscle mass is maintained; however, with aging and under certain catabolic condition including cancer, renal failure or trauma, muscle protein degradation exceeds the synthesis of new proteins, and results in muscle atrophy [53]. One interesting observation was that that plum extract increased the size of growing myoblast under un-differentiated conditions, suggestive of inducing increase in cytoplasmic volumes by stimulating protein synthesis. We also measured effect of plum extract on protein synthesis and degradation in differentiated myotubules. Our data clearly demonstrated that plum extract not only increased protein synthesis but also inhibited myotubules protein degradation in response to serum starvation, demonstrating both an anabolic and anti-catabolic effect.

The activity of the plum extract appears to be at least partly mediated through IGF-1 stimulation. Several studies have shown that IGFs stimulated both proliferation and differentiation of myoblasts, and also play a role in regenerating damaged skeletal muscle [54-58]. In line with our results, prior studies have also demonstrated that plums can increase IGF-1 levels in both humans [58] and animal models [51,59]. One of the manifestations of muscle loss is associated with decreased production of IGF-1 [60]. The signaling pathway IGF-1/PI3K/Akt (Insulin like growth factor -1/phosphatidyl inositol 3-kinase/protein kinase) is considered the main mediator of normal muscle development and one of the most studied signaling molecular systems involved in muscle metabolism [61]. Akt activation leads to activation of mTOR (mammalian target of rapamycin), which is responsible for promoting protein synthesis. The Akt-mTOR signaling pathway and its downstream components (p70s6k and 4E-BPI) are attenuated with muscle wasting [62]. Further studies need to be performed to confirm the if plum extract is indeed regulating Akt activity. The identification of compound or compounds in plum responsible for stimulating IGF-1 levels in myoblast was beyond the scope of the present study. As discussed earlier, ursolic acid has been shown to increase muscle mass in mice exhibiting fasting-induced muscle atrophy [22] or diet-induced obesity [23]. Interestingly, ursolic acid has also been shown to induce IGF-1 levels in the skeletal muscle of these mice with an increased Akt phosphorylation [22,23]. During present investigation, we were not able to detetect ursolic acid in PE60 extracts due to technical limitation for detecting all polyphenols; however, other studies have reported presence of ursolic acid in plums [21]. Therefore, it is possible that ursolic to some extent may have contributed in IGF-1 mediated muscle growth in our studies.

Studies have demonstrated the anti-inflammatory effect of dried-plum or plum juice in several cellular system including lipopolysaccharide-induced macrophages $[63,64]$, splenocytes from 
ovariectomized mice [65], colorectal cells in azoxymethane-treated rats [66], heart tissues in obese rats [67] and joints of TNF-over expressing mice [25]. The antioxidation activities of plum appeared to be mediated through the inhibition of NFKB activation $[25,66,67]$. Based on these reported studies, we decided to test the effect of plum extract on NFKB activation, since oxidative stress and inflammatory responses through activation of NFKB play an important part in muscle atrophy. Activation of NFkB plays a central role in muscle atrophy in several catabolic situations including cancer cachexia $[68,69]$. We found that even a small dose of plum extract was able to almost completely inhibit ( $>80 \%$ inhibition) TNF- $\alpha$-induced NFkB activity in vitro. It is likely that the proanthocyanidins, which comprise over $70 \%$ of the polyphenols, may be involved in suppressing the inflammatory cytokine (TNF)-induced activation of NFKB, although this has not been systematically tested with the individual components of the extract.

Cancer cachexia-related morbidity and mortality are often accompanied by whole body and muscle loss $[4,7,8]$ and it is suggested that blocking muscle wasting can prolong life despite tumor growth [10]. The effect of plum extract on colon cancer cell viability, as well as its ability to protect muscle cells from colon-cancer cell induced cytotoxicity, were, therefore, also investigated. We used Colon-26 adenocarcinoma cells, which is a widely used preclinical model because it induces clinical cachexia, including its development as well as the resultant physiological and metabolic impairment $[40,69,70]$. Treating the Colon-26 colon cancer cells with plum extract caused a significant decrease in the Colon-26 cell's viability, indicating potential anti-tumor activity.

It is known that muscle wasting in cancer patients is mediated through factors released from tumor in circulation [71-74]. Studies have shown that elevated circulating levels of IL-6 mediated skeletal muscle cell death in severely cachectic mice with colon cancer [75]. Our studies found that plum extract can protect $\mathrm{C} 2 \mathrm{C} 12$ myotubules from cytotoxicity induced by soluble factors released by the Colon-26 cells. The exact pathways leading to reduced cell viability in response to tumor induced soluble factors are not known, but it is possible that both atrophy and apoptosis may be attenuated by the plum extract. It is also possible that compound(s) in plum extract may directly affect colon cells to inhibit secretion of inflammatory cytokines. Future studies need to be conducted to elucidate the molecular mechanism involved in the anti-cytotoxic activity of the plum extract.

Our current studies have several limitations. The study was performed using an in vitro system that may not represent the complexities of an in vivo system. Furthermore, polyphenols in the plum extract can undergo biotransformation in vivo, which could either enhance or diminish the anabolic of plum extract on muscle as well as its anti-inflammatory benefit. However, previous human studies with dried plum still demonstrated its ability to activate IGF-1 as well as its anti-inflammatory benefits, indicating that biotransformation may not result in loss of these effects observed in our study.

\section{Conclusions}

In conclusion, the polyphenol-enriched plum extract has both anti-catabolic and anabolic effects on muscle cells, as well as myogenic potential. In addition, this plum extract exhibited anti-cytotoxic properties in response to soluble factors released from cancer cells. Thus, plum extract may be a useful intervention to be considered for cancer cachexia or other chronic disease-induced cachexia involving inflammation. These results need to be confirmed in an animal model of cachexia, followed by clinical translation.

Author Contributions: Conceptualization: R.A.S., and S.L.P.; Experimentation and Data collection: F.A.A., H.L., P.K., P.W.J.; Manuscript writing: R.A.S., P.W.J., and S.L.P.

Funding: The study was partly funded by a grant from Abbott-Nutrition, Columbus, $\mathrm{OH}$, and by Evans-Allen grant from USDA.

Acknowledgments: The financial support to Faten A. Alsolmei was provided by Saudi Arabian Culture Mission, Kingdom of Saudi Arabia.

Conflicts of Interest: Suzette Pereira and Paul Johns are currently employed by Abbott. Padmavathy Krishnan is an ex-Abbott employee. Rafat Siddiqui, Haiwen Li, and Faten Alsolmei have no conflict of interest. 


\section{References}

1. Nixon, D.W.; Heymsfield, S.B.; Cohen, A.E.; Lutne, M.H.; Ansley, J.; Lawson, D.H.; Rudman, D. Protein calorie under-nutrition in hospitalized cancer patients. Am. J. Med. 1980, 68, 683-690. [CrossRef]

2. Warren, S. The immediate causes of death in cancer. Am. J. Med. Sci. 1932, 184, 610-616. [CrossRef]

3. Evans, W.J.; Morley, J.E.; Argiles, J.; Bales, C.; Baracos, V.; Guttridge, D.; Jatoi, A.; Kalantar-Zadeh, K.; Lochs, H.; Mantovani, G.; et al. Cachexia: A new definition. Clin. Nutr. 2008, 27, 793-799. [CrossRef]

4. Fearon, K.C.; Glass, D.J.; Guttridge, D.C. Cancer cachexia: Mediators, signaling, and metabolic pathways. Cell Metab. 2012, 16, 153-166. [CrossRef] [PubMed]

5. Fearon, K.; Strasser, F.; Anker, S.D.; Bosaeus, I.; Bruera, E.; Fainsinger, R.L.; Jatoi, A.; Loprinzi, C.; MacDonald, N.; Mantovani, G.; et al. Definition and classification of cancer cachexia: An international consensus. Lancet Oncol. 2011, 12, 489-495. [CrossRef]

6. Lieffers, J.R.; Mourtzakis, M.; Hall, K.D.; McCargar, L.J.; Prado, C.M.; Baracos, V.E. A viscerally driven cachexia syndrome in patients with advanced colorectal cancer: Contributions of organ and tumor mass to whole-body energy demands. Am. J. Clin. Nutr. 2009, 89, 1173-1179. [CrossRef]

7. Ravasco, P.; Monteiro-Grillo, I.; Vidal, P.M.; Camilo, M.E. Dietary counseling improves patient outcomes: A prospective, randomized, controlled trial in colorectal cancer patients undergoing radiotherapy. J. Clin. Oncol. 2005, 23, 1431-1438. [CrossRef] [PubMed]

8. Bapuji, S.B.; Sawatzky, J.A. Understanding weight loss in patients with colorectal cancer: A human response to illness. Oncol. Nurs. Forum 2010, 37, 303-310. [CrossRef]

9. Houten, L.; Reilley, A.A. An investigation of the cause of death from cancer. J. Surg. Oncol. 1980, 13, 111-116. [CrossRef] [PubMed]

10. Benny Klimek, M.E.; Aydogdu, T.; Link, M.J.; Pons, M.; Koniaris, L.G.; Zimmers, T.A. Acute inhibition of myostatin-family proteins preserves skeletal muscle in mouse models of cancer cachexia. Biochem. Biophys. Res. Commun. 2010, 391, 1548-1554. [CrossRef]

11. Gomes-Marcondes, M.C.; Tisdale, M.J. Induction of protein catabolism and the ubiquitin-proteasome pathway by mild oxidative stress. Cancer Lett. 2002, 180, 69-74. [CrossRef]

12. Powers, S.K.; Kavazis, A.N.; McClung, J.M. Oxidative stress and disuse muscle atrophy. J. Appl. Phys. 2007, 102, 2389-2397.

13. Powers, S.K.; Kavazis, A.N.; DeRuisseau, K.C. Mechanisms of disuse muscle atrophy: Role of oxidative stress. Am. J. Physiol. Regul. Integr. Comp. Physiol. 2005, 288, 337-344. [CrossRef] [PubMed]

14. Reid, M.B.; Moylan, J.S. Beyond atrophy: Redox mechanisms of muscle dysfunction in chronic inflammatory disease. J. Physiol. 2011, 589, 2171-2179. [CrossRef]

15. Siddiqui, R.A.; Hassan, S.; Harvey, K.A.; Rasool, T.; Das, T.; Mukerji, P.; DeMichele, S. Attenuation of proteolysis and muscle wasting by curcumin C3 complex in MAC16 colon tumour-bearing mice. Br. J. Nutr. 2009, 102, 967-975. [CrossRef]

16. Lambert, K.; Coisy-Quivy, M.; Bisbal, C.; Sirvent, P.; Hugon, G.; Mercier, J.; Avignon, A.; Sultan, A. Grape polyphenols supplementation reduces muscle atrophy in a mouse model of chronic inflammation. Nutrition 2015, 31, 275-283. [CrossRef] [PubMed]

17. Wang, B.; Yang, G.; Liang, X.; Zhu, M.; Du, M. Grape seed extract prevents skeletal muscle wasting in interleukin 10 knockout mice. BMC Complement. Altern. Med. 2014, 14, 162. [CrossRef]

18. Dorchies, O.M.; Wagner, S.; Buetler, T.M.; Ruegg, U.T. Protection of dystrophic muscle cells with polyphenols from green tea correlates with improved glutathione balance and increased expression of 67LR, a receptor for (-)-epigallocatechin gallate. BioFactors 2009, 35, 279-294. [CrossRef]

19. Meador, B.M.; Mirza, K.A.; Tian, M.; Skelding, M.B.; Reaves, L.A.; Edens, N.K.; Pereira, S.L. The green tea polyphenol Epigallocatechin-3-Gallate (EGCg) attenuates skeletal muscle atrophy in a rat model of sarcopenia. J. Frailty Aging 2015, 4, 209-215.

20. Wang, H.; Lai, Y.J.; Chan, Y.L.; Li, T.L.; Wu, C.J. Epigallocatechin-3-gallate effectively attenuates skeletal muscle atrophy caused by cancer cachexia. Cancer Lett. 2011, 305, 40-49. [CrossRef]

21. Liu, J. Pharmacology of oleanolic acid and ursolic acid. J. Ethnopharmacol. 1995, 49, 57-68. [CrossRef]

22. Kunkel, S.D.; Suneja, M.; Ebert, S.M.; Bongers, K.S.; Fox, D.K.; Malmberg, S.E.; Alipour, F.; Shields, R.K.; Adams, C.M. mRNA expression signatures of human skeletal muscle atrophy identify a natural compound that increases muscle mass. Cell Metab. 2011, 8, 627-638. [CrossRef] 
23. Kunkel, S.D.; Elmore, C.J.; Bongers, K.S.; Ebert, S.M.; Fox, D.K.; Dyle, M.C.; Bullard, S.A.; Adams, C.M. Ursolic acid increases skeletal muscle and brown fat and decreases diet-induced obesity, glucose intolerance and fatty liver disease. PLoS One 2012, 7, e39332. [CrossRef]

24. Stacewicz-Sapuntzakis, M. Dried plums and their products: Composition and health effects-an updated review. Crit. Rev. Food Sci. Nutr. 2013, 53, 277-302. [CrossRef]

25. Mirza, F.; Lorenzo, J.; Drissi, H.; Lee, F.Y.; Soung, D.Y. Dried plum alleviates symptoms of inflammatory arthritis in TNF transgenic mice. J. Nutr. Biochem. 2018, 52, 54-61. [CrossRef] [PubMed]

26. Kim, D.-O.; Jeong, S.W.; Lee, C.Y. Antioxidant capacity of phenolic phytochemicals from various cultivars of plums. Food Chem. 2003, 81, 321-326. [CrossRef]

27. Ramos, S.; Alia, M.; Bravo, L.; Goya, L. Comparative effects of food-derived polyphenols on the viability and apoptosis of a human hepatoma cell line (HepG2). J. Agric. Food Chem. 2005, 53, 1271-1280. [CrossRef] [PubMed]

28. Yu, M.H.; Im, H.G.; Kim, H.I.; Lee, I.S. Induction of apoptosis by immature plum in human hepatocellular carcinoma. J. Med. Food 2009, 12, 518-527. [CrossRef]

29. Yu, M.H.; Gwon, I.H.; Gyu, L.S.; Kim, D.I.; Jeong, S.H.; Lee, I.S. Inhibitory effect of immature plum on PMA-induced MMP-9 expression in human hepatocellular carcinoma. Nat. Prod. Res. 2009, 23, 704-718. [CrossRef] [PubMed]

30. Rendina, E.; Hembree, K.D.; Davis, M.R.; Marlow, D.; Clarke, S.L.; Halloran, B.P.; Lucas, E.A.; Smith, B.J. Dried plum's unique capacity to reverse bone loss and alter bone metabolism in postmenopausal osteoporosis model. PLoS One 2013, 8, e60569. [CrossRef]

31. Arjmandi, B.H.; Johnson, S.A.; Pourafshar, S.; Navaei, N.; George, K.S.; Hooshmand, S.; Sheau, C.; Chai, S.C.; Akhavan, N.S. Bone-protective effects of dried plum in postmenopausal women: Efficacy and possible mechanisms. Nutrients 2017, 9, 496. [CrossRef] [PubMed]

32. Hooshmand, S.; Brisco, J.R.; Arjmandi, B.H. The effect of dried plum on serum levels of receptor activator of NF- $\mathrm{kB}$ ligand, osteoprotegerin and sclerostin in osteopenic postmenopausal women: A randomised controlled trial. Br. J. Nutr. 2014, 112, 55-60. [CrossRef]

33. Halloran, B.P.; Wronski, T.J.; VonHerzen, D.C.; Chu, V.; Xia, X.; Pingel, J.E.; Williams, A.A.; Smith, B.J. Dietary dried plum increases bone mass in adult and aged male mice. J. Nutr. 2010, 140, 1781-1787. [CrossRef] [PubMed]

34. Niketic-Aleksic, G.K.; Hrazdina, G. Quantitative analysis of the anthocyanin content in grape juices and wines. LWT-FOOD. SCI. TECHNOL. 1972, 5, 163-165.

35. Yu, L.; Haley, S.; Perret, J.; Harris, M. Antioxidant properties of extracts from hard winter wheat. Food Chem. 2002, 78, 457-461. [CrossRef]

36. Parry, J.W.; Su, L.; Moore, J.; Cheng, Z.; Luther, M.; Jaladanki, R.; Wang, J.; Yu, L. Chemical Compositions, Antioxidative Capacities, and Anti-Proliferative Activities of Selected Fruit Seed Flours. J. Agric. Food Chem. 2006, 54, 3773-3778. [CrossRef]

37. Cheng, Z.; Moore, J.; Yu, L. High-throughput relative DPPH radical scavenging capacity assay. J. Agric. Food Chem. 2006, 54, 7429-7436. [CrossRef] [PubMed]

38. Re, R.; Pellegrini, N.; Proteggente, A.; Pannala, A.; Yang, M.; Rice-Evens, C. Antioxidant activity applying an improved ABTS radical cation decolorization assay. Free Radic. Bio. Med. 1999, 26, 1231-1237. [CrossRef]

39. Siddiqui, R.A.; Harvey, K.A.; Xu, Z.; Natarajan, S.K.; Davisson, V.J. Characterization of lovastatin-docosahexaenoate anticancer properties against breast cancer cells. Bioorg. Med. Chem. 2014, 22, 1899-1908. [CrossRef]

40. Yuan, L.; Hani, J.; Mmeng, Q.; Xi, Q.; Zhuang, Q.; Jiang, Y.; Han, Y.; Zhang, B.; Fang, Z.; Wu, G. Muscle-specific E3 ubiquitin ligases are involved in muscle atrophy of cancer cachexia: An in vitro and in vivo study. Oncol. Rept. 2015, 33, 2261-2268. [CrossRef]

41. Nakatani, N.; Kayano, S.; Kikuzaki, H.; Sumino, K.; Katagiri, K.; Mitani, T. Identification, quantitative determination, and antioxidative activities of chlorogenic acid isomers in prune (Prunus domestica L.). J Agric. Food Chem 2000, 48, 5512-5516. [CrossRef]

42. Graef, J.L.; Rendina-Ruedya, E.; Crocketta, E.K.; Ouyanga, P.; King, J.B.; Cichewiczb, R.H.; Lucasa, E.A.; Smitha, B.J. Select polyphenolic fractions from dried plum enhance osteoblast activity through BMP-2 signaling. J. Nutr. Biochem. 2018, 55, 59-67. [CrossRef] 
43. Graef, J.L.; Ouyanga, P.; Wanga, Y.; Rendina-Ruedya, E.; Lernerc, M.R.; Marlowb, D.; Lucasa, E.A.; Smith, B.J. Dried plum polyphenolic extract combined with vitamin $\mathrm{K}$ and potassium restores trabecular and cortical bone in osteopenic model of postmenopausal bone loss. J. Funct. Foods 2018, 42, 262-270. [CrossRef] [PubMed]

44. Ferreyra, M.L.F.; Rius, S.P.; Casati, P. Flavonoids: Biosynthesis, biological functions, and biotechnological applications. Front Plant Sci. 2012, 3, 222.

45. Bener, M.; Ozyurek, M.; Guçlu, K.; Apak, P. Optimization of microwave-assisted extraction of curcumin from Curcuma longa L. (turmeric) and evaluation of antioxidant activity in multi-test systems. Rec. Nat. Prod. 2016, 10, 542-554.

46. Pekal, A.; Drozdz, P.; Pyrzynska, K. Comparison of the antioxidant properties of commonly consumed commercial teas. Int. J. Food Prop. 2012, 15, 1101-1109. [CrossRef]

47. Forester, S.C.; Lambert, J.D. Antioxidant effects of green tea. Mol. Nutr. Food Res. 2011, 55, 844-854. [CrossRef] [PubMed]

48. Arfan, M.; Khan, R.; Rybarczyk, A.; Amarowicz, R. Antioxidant activity of mulberry fruit extracts. Int. J. Mol. Sci. 2012, 13, 2472-2480. [CrossRef] [PubMed]

49. Gil, M.I.; Tomas-Barberan, F.A.; Hess-Pierce, B.; Holcroft, D.M.; Kader, A.A. Antioxidant activity of pomegranate juice and its relationship with phenolic composition and processing. J. Agric. Food Chem. 2000, 48, 4581-4589. [CrossRef]

50. Deyhim, F.; Stoecker, B.J.; Brusewitz, G.H.; Devareddy, L.; Arjmandi, B.H. Dried plum reverses bone loss in an osteopenic rat model of osteoporosis. Menopause 2005, 2, 755-762. [CrossRef]

51. Franklin, M.; Bu, S.Y.; Lerner, M.R.; Lancaster, E.A.; Bellmer, D.; Marlow, D.; Lightfoot, S.A.; Arjmandi, B.H.; Brackett, D.J.; Lucas, E.A.; et al. Dried plum prevents bone loss in a male osteoporosis model via IGF-I and the RANK pathway. Bone 2006, 39, 1331-1342. [CrossRef]

52. Vizzotto, M.; Porter, W.; Byrne, D.; Cisneros-Zevallos, L. Polyphenols of selected peach and plum genotypes reduce cell viability and inhibit proliferation of breast cancer cells while not affecting normal cells. Food Chem. 2014, 164, 363-370. [CrossRef]

53. Cohen, S.; Nathan, J.A.; Goldberg, A.L. Muscle wasting in disease: Molecular mechanisms and promising therapies. Nat. Rev. Drug Discov. 2015, 14, 58-74. [CrossRef]

54. Florini, J.R.; Ewton, D.Z.; Coolican, S.A. Growth hormone and the insulin-like growth factor system in myogenesis. Endocr. Rev. 1996, 17, 481-517.

55. Coleman, M.E.; DeMayo, F.; Yin, K.C.; Lee, H.M.; Geske, R.; Montgomery, C.; Schwartz, R.J. Myogenic vector expression of insulin-like growth factor 1 stimulates muscle cell differentiation and myofiber hypertrophy in transgenic mice. J. Biol. Chem. 1995, 270, 12109-12116. [CrossRef] [PubMed]

56. Jennische, E.; Skottner, A.; Hansson, H.A. Satellite cells express the trophic factor IGF-1 in regenerating skeletal muscle cell. Acta Physiol. Scand. 1987, 129, 9-15. [CrossRef]

57. Jannische, E.; Hansson, H.A. Regenerating skeletal muscle cells express insulin-like growth factor I. Acta Physiol. Scand. 1987, 130, 327-332. [CrossRef]

58. Arjmandi, B.H.; Khalil, D.A.; Lucas, E.A.; Georgis, A.; Stoecker, B.J.; Hardin, C.; Payton, M.E.; Wild, R.A. Dried plums improve indices of bone formation in postmenopausal women. J. Womens Health Gend. Based Med. 2002, 11, 61-68. [CrossRef] [PubMed]

59. Smith, B.J.; Bu, S.Y.; Wang, Y.; Rendina, E.; Lim, Y.F.; Marlow, D.; Clarke, S.L.; Cullen, D.M.; Lucas, E.A. A comparative study of the bone metabolic response to dried plum supplementation and PTH treatment in adult, osteopenic ovariectomized rat. Bone 2014, 58, 151-159. [CrossRef]

60. Costelli, P.; Muscaritoli, M.; Bossola, M.; Penna, F.; Reffo, P.; Bonetto, A.; Busquets, S.; Bonelli, G.; Lopez-Soriano, F.J.; Doglietto, G.B.; et al. IGF-1 is downregulated in experimental cancer cachexia. Am. J. Physiol. Regul. Integr. Comp Physiol. 2006, 291, R674-R683. [CrossRef]

61. Schiaffino, S.; Mammucari, C. Regulation of skeletal muscle growth by the IGF1-Akt/PKB pathway: Insights from genetic models. Skeletal Muscle 2011. [CrossRef] [PubMed]

62. Eley, H.L.; Russell, S.T.; Tisdale, M.J. Effect of branched-chain amino acids on muscle atrophy in cancer cachexia. Biochem. J. 2007, 407, 113-120. [CrossRef] [PubMed]

63. Bu, S.Y.; Lerner, M.; Stoecker, B.J.; Boldrin, E.; Brackett, D.J.; Lucas, E.A.; Smith, B.J. Dried plum polyphenols inhibit osteoclastogenesis by downregulating NFATc1 and inflammatory mediators. Calcif. Tissue Int. 2008, 82, 475-488. [CrossRef] [PubMed] 
64. Hooshmand, S.; Kumar, A.; Zhang, J.Y.; Johnson, S.A.; Chai, S.C.; Bahram, H.; Arjmandi, B.H. Evidence for anti-inflammatory and antioxidative properties of dried plum polyphenols in macrophage RAW 264.7 cells. Food Funct. 2015, 6, 1719-1725. [CrossRef]

65. Rendina, E.; Lima, Y.F.; Marlowb, D.; Wanga, Y.; Clarkea, S.L.; Kuvibidilaa, S.; Lucasa, E.A.; Brenda, J.; Smith, B.J. Dietary supplementation with dried plum prevents ovariectomy-induced bone loss while modulating the immune response in C57BL/6J mice. J. Nutr. Biochem. 2012, 23, 60-68. [CrossRef]

66. Banerjee, N.; Kim, H.; Talcott, S.T.; Turner, N.D.; Byrne, D.H.; Mertens-Talcott, S.U. Plum polyphenols inhibit colorectal aberrant crypt foci formation in rats: Potential role of the miR-143/protein kinase B/mammalian target of rapamycin axis. Nutr. Res. 2016, 36, 1105-1113. [CrossRef] [PubMed]

67. Noratto, G.; Martino, H.S.D.; Simbo, S.; Byrne, D.; Mertens-Talcott, S.U. Consumption of polyphenol-rich peach and plum juice prevents risk factors for obesity-related metabolic disorders and cardiovascular disease in Zucker rats. J. Nutr. Biochem. 2015, 26, 633-641. [CrossRef]

68. Guttridge, D.C.; Mayo, M.W.; Madrid, L.V.; Wang, C.-Y.; Baldwin, A.S., Jr. NF-kB-induced loss of MyoD messenger RNA: Possible role in muscle decay and cachexia. Science 2000, 289, 2363-2366. [CrossRef] [PubMed]

69. Aulino, P.; Berardi, E.; Cardillo, V.M.; Rizzuto, E.; Perniconi, B.; Ramina, C.; Padula, F.; Spugnini, E.P.; Baldi, A.; Faiola, F.; et al. Molecular, cellular and physiological characterization of the cancer cachexia-inducing C26 colon carcinoma in mouse. BMC Cancer 2010, 10, 363. [CrossRef]

70. Tian, M.; Kliewer, K.L.; Asp, M.L.; Stout, M.B.; Belury, M.A. c9t11-Conjugated linoleic acid-rich oil fails to attenuate wasting in colon-26 tumor-induced late-stage cancer cachexia in male CD2F1 mice. Mol. Nutr. Food Res. 2010, 55, 268-277. [CrossRef]

71. Siddiqui, R.; Pandya, D.; Harvey, K.; Zaloga, G.P. Nutrition modulation of cachexia/proteolysis. Nutr. Clin. Pract. 2006, 21, 55-67. [CrossRef]

72. Siddiqui, R.A.; Williams, J.F. Tentative identification of the toxohormones of cancer cachexia: Roles of vasopressin, prostaglandin E2 and cachectic-TNF. Biochem. Int. 1990, 20, 787-797.

73. Tisdale, M.J. Mechanisms of Cancer Cachexia. Physiol Rev. 2009, 89, 381-410. [CrossRef]

74. Lorite, M.J.; Smith, H.J.; Arnold, J.A.; Morris, A.; Thompson, M.G.; Tisdale, M.J. Activation of ATP-ubiquitin-dependent proteolysis in skeletal muscle in vivo and murine myoblasts in vitro by a proteolysis-inducing factor (PIF). Brit. J. Cancer 2001, 85, 297-302. [CrossRef] [PubMed]

75. Baltgalvis, K.A.; Berger, F.G.; Peña, M.M.O.; Davis, J.M.; White, J.P.; Carson, J.A. Activity level, apoptosis, and development of cachexia in Apc mice. J. Appl. Physiol. 2010, 109, 1155-1161. [CrossRef] [PubMed] 